\title{
Prohormone convertase and autocrine growth factor mRNAs are coexpressed in small cell lung carcinoma
}

\section{P Rounseville and T P Davis}

Department of Pharmacology, College of Medicine, The University of Arizona, Tucson, Arizona 85724, USA

(Requests for offprints should be addressed to T P Davis)

\begin{abstract}
A hallmark of small cell lung carcinoma (SCLC) is the expression of autocrine growth factors such as neurotensin and gastrin-releasing peptide, which bind to cellular receptors and stimulate cell division. The biological activity of autocrine growth factors requires the concurrent expression of prohormone convertases that cleave the growth factors to their active form, suggesting the expression of these genes is linked in SCLCs. RNase protection assays were used to detect the expression of autocrine growth factor and prohormone convertase mRNAs in a panel of lung cancer cell lines. These mRNAs
\end{abstract}

are coexpressed in SCLC and lung carcinoid cell lines, but not in normal lung epithelium or in non-small cell lung cancers. These findings, together with earlier results from our laboratory, suggest the expression of prohormone convertases has an important role in the development and maintenance of the SCLC phenotype and that autocrine growth factor and prohormone convertase genes respond to a common transcriptional activator in SCLC.

Fournal of Molecular Endocrinology (2000) 25, 121-128

\section{INTRODUCTION}

A hallmark of small cell lung carcinoma (SCLC) is the expression of autocrine growth factors such as $\beta$-endorphin (Davis et al. 1989), neurotensin (Davis et al. 1991), insulin-like growth factors (Nakanishi et al. 1988), and gastrin-releasing peptide (GRP; Cuttitta et al. 1985, Moody et al. 1981), which bind to cellular receptors and stimulate cell division. These peptide hormones are initially synthesized as biologically inert prohormones which are subsequently cleaved to their active form by a family of enzymes called the prohormone convertases. Prohormone convertases are endoproteases that cleave proproteins and prohormones at specific pairs of basic amino acids (Barr 1991, Steiner et al. 1992). Seven mammalian prohormone convertases have been identified and categorized according to tissue distribution. Among these, PC1 (also known as PC3) and PC2, are expressed exclusively in endocrine and neuroendocrine tissues, where they process precursor proteins that are in transit through regulated secretory pathways (Smeekens et al. 1991, Day et al. 1992, Seidah et al. 1993). Recent studies indicate that pro-neurotensin is processed by PC1 in intestinal cells and by $\mathrm{PC} 2$ in neuronal cells (Rovère et al. 1996). The prohormone convertase that processes pro-GRP has not been identified, however, pro-GRP is cleaved at a dibasic site (Lys-Lys) which is consistent with its processing by either $\mathrm{PC} 1$ or $\mathrm{PC} 2$.

In addition to the prohormone convertases, the biological activity of an autocrine growth factor requires the concurrent activity of several other gene products, including the amidating enzyme peptidylglycine $\alpha$-amidating monooxygenase (Saldise et al. 1996), the molecular chaperone 7B2 (Braks \& Martens 1995, Zhu \& Lindberg 1995), and growth factor receptors, suggesting that the expression of these functionally related genes is linked. The broad goal of our research is to elucidate the mechanisms that regulate the expression of autocrine growth factors in neuroendocrine tumors. Our initial step has been to establish whether the genes for autocrine growth factors and the prohormone convertases that process them are coordinately transcribed in SCLCs. To this end, we screened a panel of human lung cancer cell lines for the expression of two autocrine growth factors (neurotensin and gastrin-releasing peptide) and two neuroendocrine-specific processing enzymes (PC1 and PC2). It is hoped that an improved 
understanding of the cellular factors and mechanisms that lead to SCLC will facilitate the development of novel drugs and strategies for inhibiting the growth of SCLCs and other neuroendocrine tumors.

\section{MATERIALS AND METHODS}

\section{Cell culture}

The following NCI series of lung cell types was obtained from the American Type Culture Collection (ATCC, Rockville, MD, USA): H209, H345, H510, H69, H146, N592 (classical SCLCs), N417 (variant SCLC), H23 (adenocarcinoma, NSCLC), H157 (squamous cell carcinoma, NSCLC) and H727 (carcinoid). The growth and biochemical characteristics of these cell types, including bombesin-like immunoreactivity, have been described (Carney et al. 1985). The cells were grown in antibiotic-free RPMI 1640 (JRH Biosciences, Lenexa, KS, USA) supplemented with $10 \%$ heat-inactivated bovine calf serum (HyClone Laboratories, Inc., Logan, UT, USA) at $37^{\circ} \mathrm{C}$ in a humidified atmosphere of $5 \% \mathrm{CO}_{2}$. The normal human lung fibroblast line CCD-19 Lu was also obtained from ATCC and grown in Eagle's minimal essential medium (Hazleton Biologics, Inc., Lenexa, KS, USA) supplemented with non-essential amino acids (Sigma, St Louis, MO, USA) and 10\% heat-inactivated bovine calf serum (HyClone Laboratories, Inc.). Normal human small airway epithelial cells (SAECs) were purchased from Clonetics Corporation (San Diego, CA, USA) and grown in serum-free small airway epithelial cell media according to the supplier's instructions.

\section{Plasmid constructs}

The human PC1 construct (hPC1 15-5) was a gift of R Day (DeSéve Laboratories of Biochemical Neuroendocrinology, Montreal, Quebec, Canada). Linearization with BglII and transcription with T7 RNA polymerase generates an antisense RNA probe of $\sim 300$ bases; $\sim 210$ bases are protected from RNase digestion by hybridization to PC1 mRNA. Plasmid hPC2 was obtained from M Mbikay (Institut de Recherches Cliniques de Montreal, Universite de Montreal, Quebec, Canada). phPC2 contains 193 bases of human PC2 cDNA cloned into the PstI/BamHI site of pSP72. Cleavage with BamHI and transcription with SP6 RNA polymerase generates an antisense probe of 220 bases, 193 of which are protected from RNase degradation by hybridization to PC2 mRNA. The human neurotensin plasmid, phNTE0.9, was a generous gift of
P Dobner (Department of Molecular Genetics and Microbiology, University of Massachusetts Medical Center, Worcester, MA, USA). phNTE0. 9 consists of an 806-base fragment containing exon 1 and portions of the $5^{\prime}$-flanking region and intron 1 cloned into EcoRI site of pGEM4 as described by Bean et al. (1992). Linearization with SmaI and transcription with SP6 RNA polymerase generates a 834 base antisense RNA probe; 184 bases are protected from RNase degradation by hybridization to neurotensin mRNA. ppGRP was provided by James Battey (NIH, Bethesda, MD, USA). The plasmid contains $1 \mathrm{~kb}$ human GRP cDNA cloned into the HindIII site of pSP64 (Promega, Madison, WI, USA). A 300-base antisense probe was generated by cutting with PvuII and transcribing with SP6 RNA polymerase. The probe migrates as a doublet, presumably because of strong secondary structure. pTRI- $\beta$ actin-human and pTRI- $\beta$-actin-125-human were purchased from Ambion (Austin, TX, USA) in linearized form. pTRI- $\beta$-actin antisense RNA protects 245 bases of $\beta$-actin mRNA, whereas pTRI- $\beta$ actin-125 probe protects 127 bases of $\beta$-actin mRNA.

\section{In vitro transcription}

${ }^{32} \mathrm{P}$-labeled antisense RNA probes were generated using an RNA transcription kit from Stratagene (La Jolla, CA, USA). For the prohormone convertase and growth factor probes, $5 \mu \mathrm{l}$ $\left[\alpha^{32} \mathrm{P}\right] \mathrm{UTP} \quad(800 \mathrm{Ci} / \mathrm{mmol}$; NEN Life Science Products, Boston, MA, USA) and $1 \mu$ unlabeled $250 \mathrm{M}$ UTP were included in a 201 reaction volume. For the $\beta$-actin probes, $1 \mu \mathrm{l}\left[\alpha^{32} \mathrm{P}\right] \mathrm{UTP}$ and $1 \mu \mathrm{l}$ unlabeled $1 \mathrm{mM}$ UTP were included in a $20 \mu \mathrm{l}$ reaction volume. Reactions were incubated at $37^{\circ} \mathrm{C}$ for $45 \mathrm{~min}$. Plasmid DNA was removed by digestion with 1 unit RNase-free DNase 1 for $15 \mathrm{~min}$ at $37^{\circ} \mathrm{C}$. Two microliters of the reaction were diluted into $500 \mu \mathrm{l}$ water and counted in a scintillation counter. Generally, $2 \mu$ diluted probe ( 20000 c.p.m.) were used for each sample in the $\mathrm{RNase}$ protection assay.

\section{RNase protection assay}

Total RNA was isolated using TRI REAGEN LS (Molecular Research Center, Inc., Cincinnati, OH, USA) according to the supplier's instructions. RNase protection assays were performed using an RPA II kit from Ambion as previously described (Waters et al. 1997). Briefly, 20000 c.p.m. antisense RNA probe was precipitated with $10 \mu \mathrm{g}$ total RNA from each cell type. The RNA pellet was 


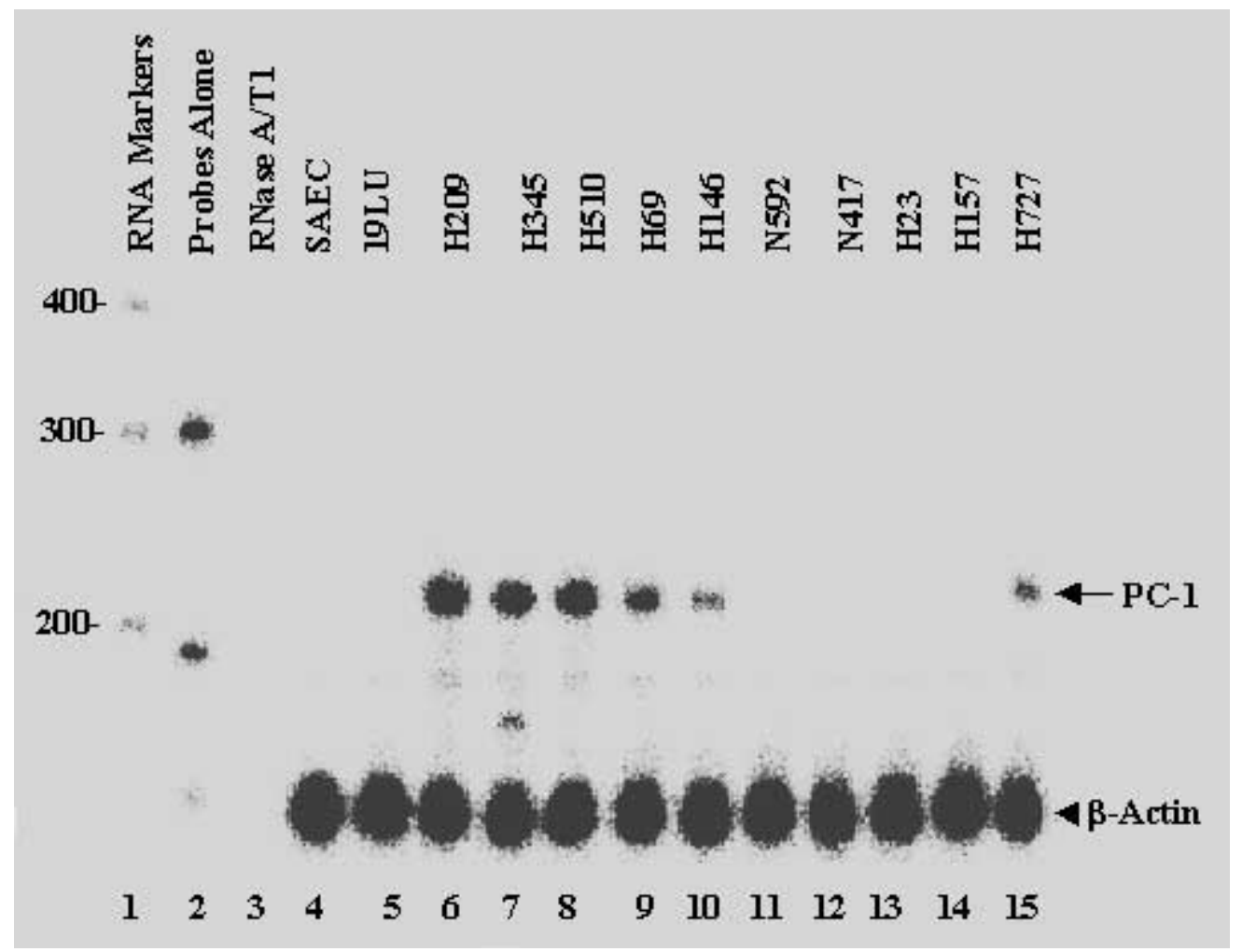

FIGURE 1. RNase protection assay of PC1 mRNA expression in human lung cell lines.

resuspended in $20 \mu$ l hybridization buffer, heated at $90{ }^{\circ} \mathrm{C}$ for $3 \mathrm{~min}$, then incubated overnight at $40-$ $45^{\circ} \mathrm{C}$. Unhybridized RNA was digested with 2001 of 1:100 dilution of stock RNase A/T1 in RNase digestion buffer for $30 \mathrm{~min}$ at $37^{\circ} \mathrm{C}$. The reaction was stopped by the addition of 3001 RNase inactivation/precipitation mixture and the products were precipitated by chilling at $-20{ }^{\circ} \mathrm{C}$ for $20 \mathrm{~min}$, followed by centrifugation at $12000 \mathrm{~g}$. The samples were resuspended in $10 \mu \mathrm{l}$ loading buffer $(95 \%$ formamide, $0.025 \%$ xylene cyanol, $0.025 \%$ bromophenol blue, $0.5 \mathrm{mM}$ EDTA, and $0.025 \%$ SDS), heated at $90{ }^{\circ} \mathrm{C}$ for $3 \mathrm{~min}$, then loaded on a $7 \mathrm{M}$ urea- $4 \%$ polyacrylamide gel and run at $300 \mathrm{~V}$ until the bromophenol blue migrated to the bottom of the gel. The gel was dried and then imaged by electronic autoradiography on a Packard InstantImager (Meriden, CT, USA).

\section{RESULTS}

To determine whether prohormone convertase genes are coexpressed with autocrine growth factor genes in SCLC, we used RNase protection assays to examine the level of PC1, PC2, neurotensin, and GRP mRNA expression in a panel of human lung cancer cell lines. We found that PC1 mRNA is not expressed in normal SAECs (Fig. 1, lane 4) or in normal lung fibroblasts (19 Lu; lane 5). In contrast, PC1 is abundantly transcribed in five of the six classical SCLC cell lines tested (H209, H345, H510, H69, and H146; lanes 6-10) and in the lung carcinoid tumor cell line H727 (lane 15). PC1 mRNA was not expressed in the classic SCLC cell line N592 (lane 11) or in the variant SCLC cell line N417 (lane 12). These two cell types were initially established by passage through nude mice (hence the $\mathrm{N}$ prefix); whether this has any effect on the expression of PC1 mRNA is unknown. Neither of the two non-SCLC cell lines - H23 (adenocarcinoma; lane 13) and H157 (squamous cell carcinoma; lane 14) - expressed detectable levels of PC1 mRNA. The $\beta$-actin signal shows that equal quantities of RNA were tested in each sample.

The transcriptional activity of the neurotensin gene was examined in the same panel of lung cancer cells. The expression of neurotensin mRNA parallels the expression of PC1 mRNA in that neurotensin mRNA is found in five of six classical SCLCs and in the lung carcinoid cell line H727, but 


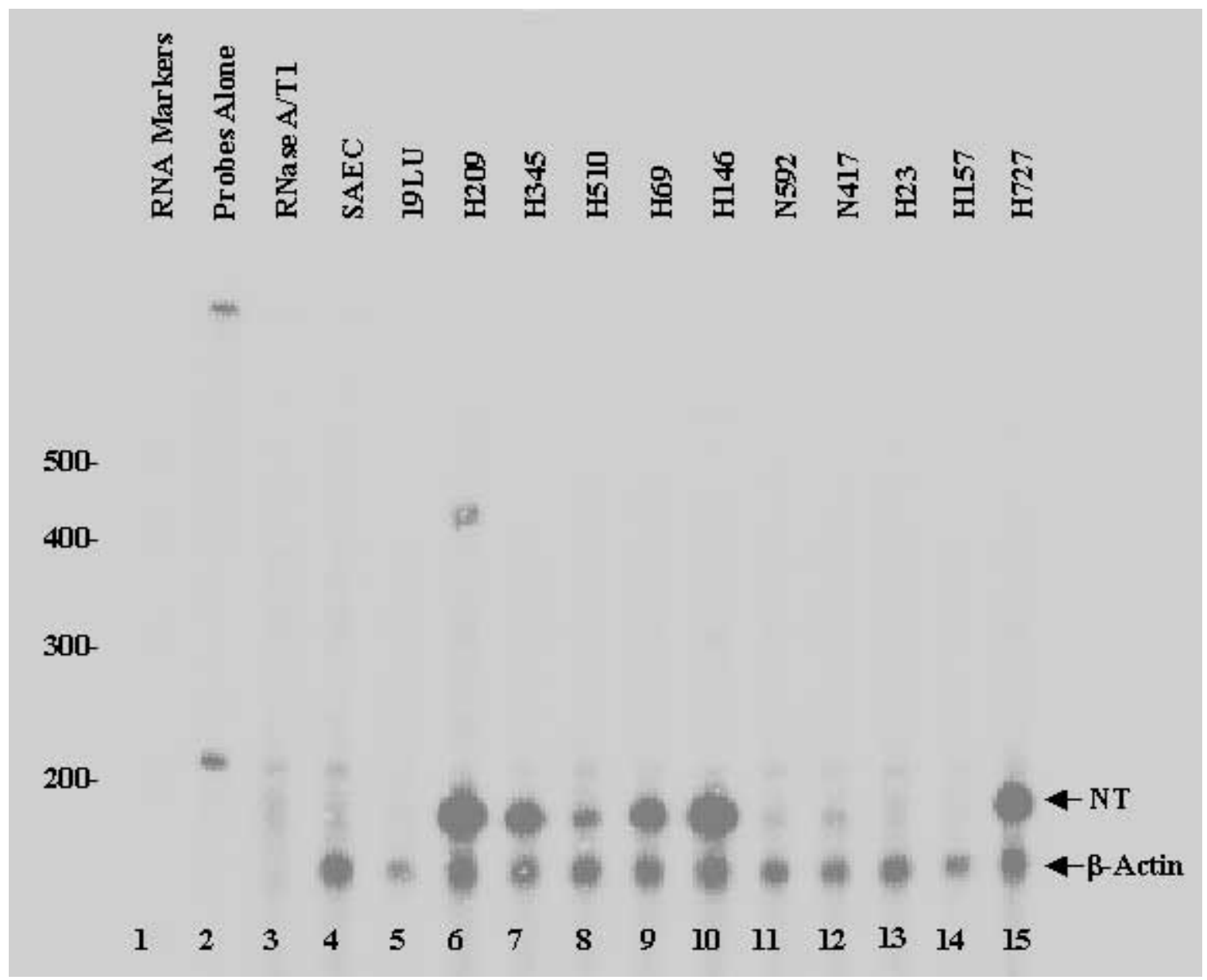

FIGURE 2. RNase protection assay of neurotensin mRNA expression in human lung cell lines.

not in the normal lung cells or in the non-SCLCs (Fig. 2).

Next, the expression of PC2 mRNA in these cell types was examined (Fig. 3). As with PC1, PC2 was expressed in five of the six classical SCLC cell types (H209, H345, H510, H69, and H146; lanes 6-10), but not in the normal lung cells (SAEC and $19 \mathrm{Lu}$; lanes 4 and 5) or in the non-SCLCs (H23 and H157; lanes 13 and 14). In contrast to PC1 and neurotensin, $\mathrm{PC} 2$ gene expression was absent in the lung carcinoid cell line H727 (Fig. 3, lane 15).

The expression of GRP mRNA (Fig. 4) among this panel of lung cancer cells parallels the expression of PC2 in that GRP mRNA is expressed in the classical SCLCs (lanes 6-10), yet is absent from the non-SCLCs (H23 and H157; lanes 13 and 14) and lung carcinoid cell line H727 (lane 15). The GRP probe migrates as a doublet, because of its strong secondary structure.

\section{DISCUSSION}

Essentially all known peptide hormones are initially synthesized as inactive precursors that require cleavage and post-translational processing for activity. The functional expression of an autocrine growth factor therefore requires the concurrent expression of several other gene products, including the prohormone convertases. This information led us to hypothesize that prohormone convertase genes would be expressed along with autocrine growth factor genes in small cell lung cancer. To examine this possibility, we isolated RNA from a panel of lung cancer cell lines and assayed for the expression of prohormone convertase and autocrine growth factor mRNAs.

The expression of PC1 mRNA in the SCLCs and carcinoid cell line, and its absence in normal lung and non-SCLCs (Fig. 1), suggest that PC1 is 


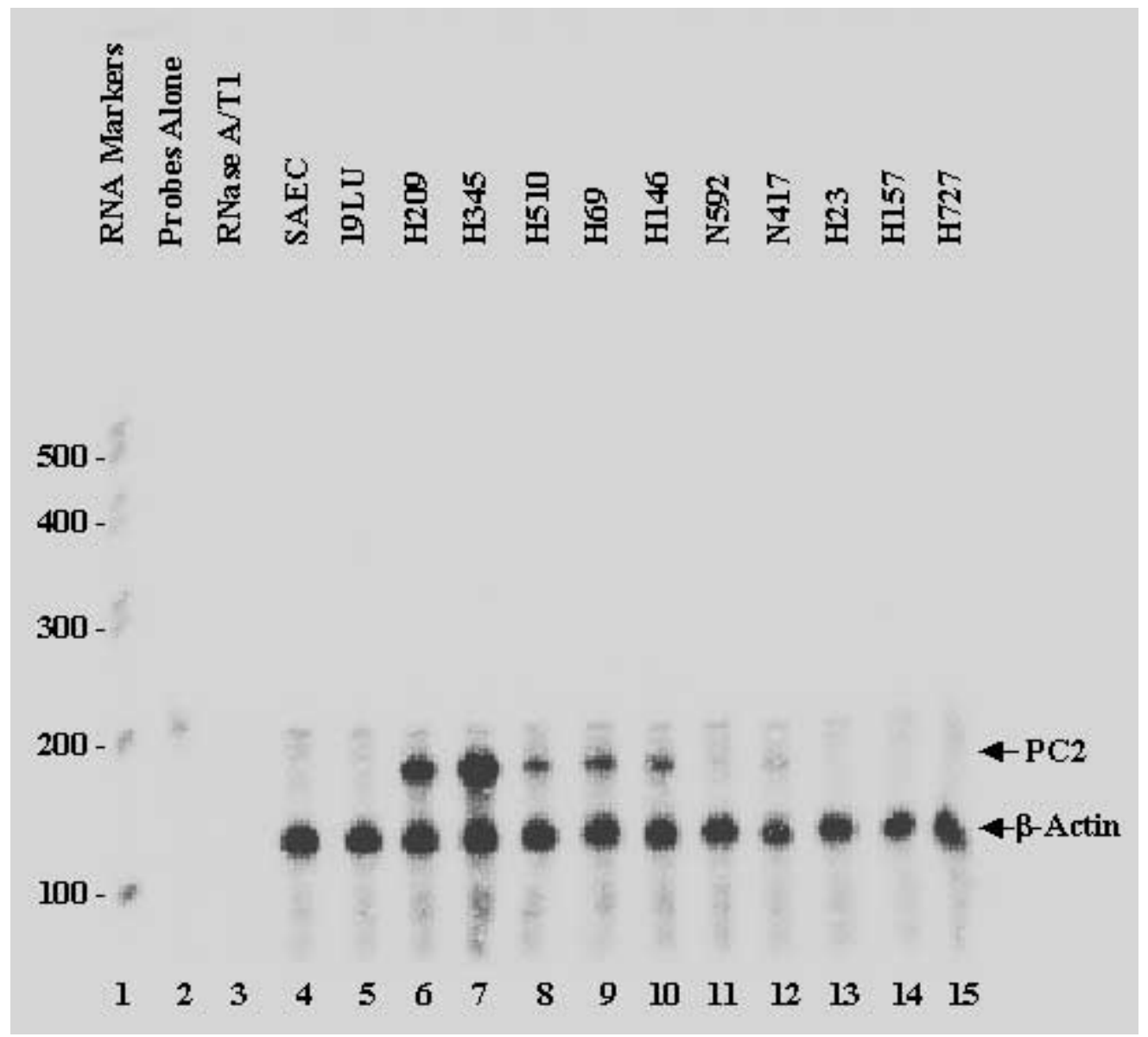

FIGURE 3. RNase protection assay of PC2 mRNA expression in human lung cell lines.

processing the autocrine growth factors found in these cell types and has an important role in the development of SCLC and carcinoid tumors of the lung. As the expression of neurotensin mRNA parallels the expression of PC1 mRNA (Fig. 2), we reason that $\mathrm{PC} 1$ is processing neurotensin in these cell types. This finding is consistent with an earlier study that shows that $\mathrm{PC} 1$ processes proneurotensin in neuroendocrine cells (Rovère et al. 1996).

PC2 and GRP are also expressed in five of the SCLC cell lines tested. However, whereas PC1 and neurotensin mRNA are expressed in the lung carcinoid cell line (H727), PC2 and GRP mRNA are not. This finding corroborates the lack of bombesin-like immunoreactivity reported for $\mathrm{H} 727$ (Moody et al. 1990) and suggests that, in this cell line, neurotensin is processed by $\mathrm{PC} 1$ rather than $\mathrm{PC} 2$. Overall, these studies support the idea that, in SCLCs and lung carcinoids, PC1 is expressed along with neurotensin, and PC2 is expressed with GRP. These findings are consistent with an earlier study

www.endocrinology.org by Mbikay et al. (1997), who found that PC1 and PC2 are overexpressed in primary SCLC tumors.

The coordinated transcription of prohormone convertase and autocrine growth factor genes in SCLCs, and their lack of expression in non-SCLCs and normal lung cells, indicates these genes are responding to the same transcriptional signals. What features of the promoters account for this apparently linked gene expression? The promoter regions for each of these genes have been cloned and partially characterized by deletion and mutational analysis (PC2, Ohagi et al. 1992; PC1, Jansen et al. 1995; GRP, Nagalla \& Spindel 1994; neurotensin, Evers et al. 1995). A cursory inspection of the promoter sequences for these genes reveals a diversity of promoter types. For example, the GRP promoter contains a TATA box, a CAAT sequence, and a single transcription start site (Nagalla \& Spindel 1994), whereas the PC1 promoter has multiple transcription start sites and no TATA box or CAAT sequence (Jansen et al. 1995). A common 


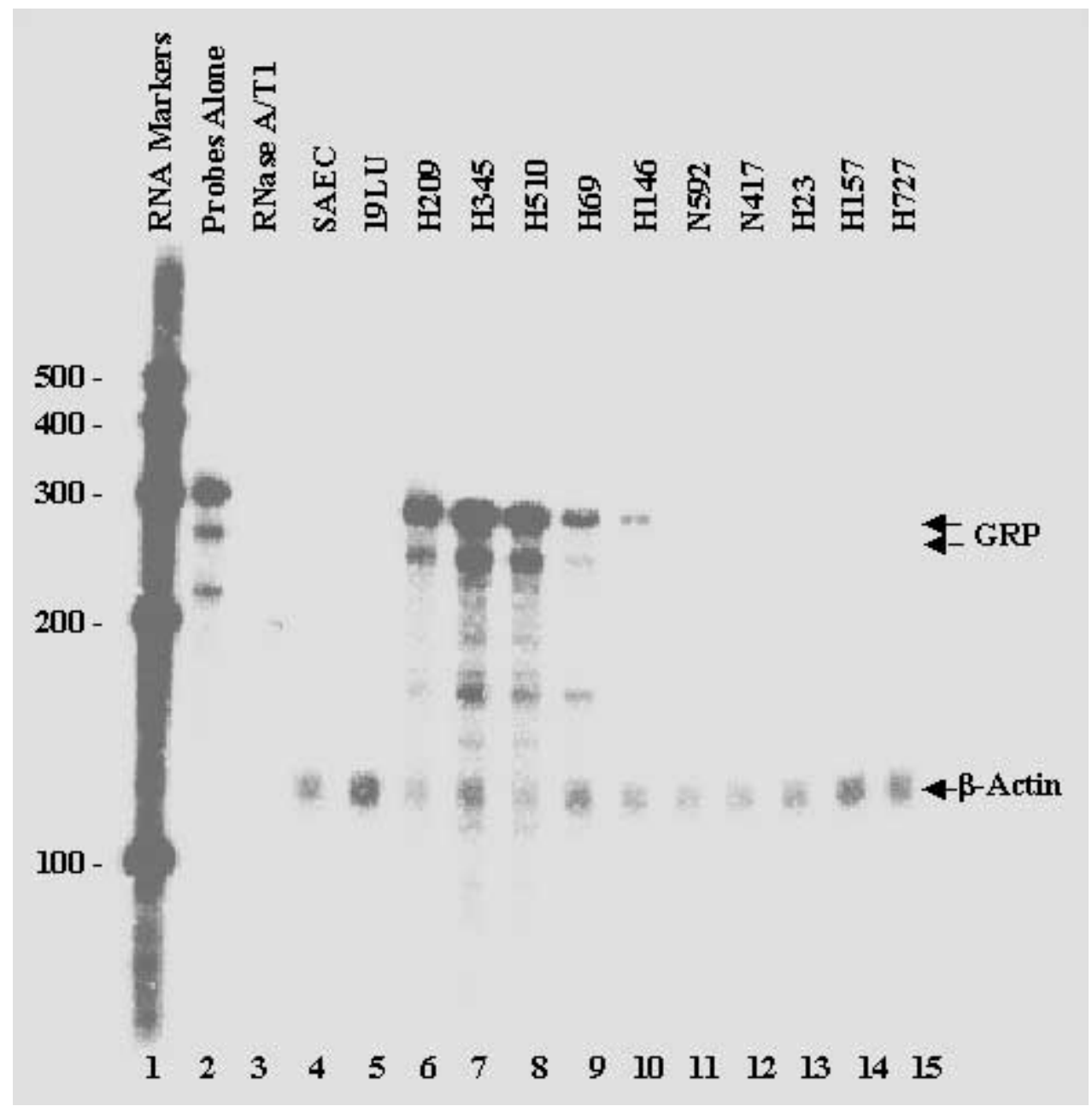

FIGURE 4. RNase protection assay of GRP mRNA expression in human lung cell lines.

feature among these genes is the presence of a consensus cyclic AMP response element (CRE), which may confer hormonal responsiveness to each promoter. We and others (Mania-Farnell et al. 1996, Jansen et al. 1995) have demonstrated that the PC1 promoter is transcriptionally activated by second messenger activators that stimulate the cAMP pathway, and that this regulation is directed through the cyclic AMP response elements.

Although the CRE is functional (to varying degrees) in these genes, it is unlikely that this feature alone is responsible for the tissue- and stage-specific expression of these genes. The GRP promoter, for example, is not particularly sensitive to increased levels of cAMP in SCLCs (Nagalla \& Spindel 1994). Moreover, whereas PC1 and neurotensin are expressed in $\mathrm{H} 727$ cells, PC2 and GRP are not. Hence, factors other than cAMP activators, are likely also to be involved in regulating the transcriptional activity of these genes. Nagalla \& Spindel (1994) have identified an upstream element in the GRP promoter that allows expression in neuroendocrine-differentiated SCLC cell lines and binds to nuclear proteins from classic (GRPexpressing) SCLCs but not variant SCLCs. In addition, Jansen et al. (1997) have shown that a novel, yet unidentified, nuclear protein, present in AtT-20 and $\beta$-TC 3 cells but not in COS- 1 cells, forms a heterodimer with c-Jun and binds to a CRE in the PC1 promoter. A purine-rich region of the neurotensin promoter, which is essential for promoter activity, also binds to nuclear proteins in neurotensin-producing cells (Evers et al. 1995). Taken together, these studies suggest that neuroendocrine-specific transcription factors work in concert with activated CRE-binding proteins to increase transcription from these genes. However, apart from the CREs, there is no striking homology 
between these promoters. Therefore, the mechanism by which these genes are coordinately expressed remains unknown. In order to understand better the activation of these SCLC-associated genes, it will be necessary to identify the transcription factors that bind to their promoter regions and regulate their expression.

The differential expression of prohormone convertases in neuroendocrine tumors may provide the basis for new treatments for these tumors. The specific inhibition of PCs may permit the selective inhibition of autocrine growth factor expression and thereby diminish the rate of cancer cell proliferation. As autocrine growth factors and prohormone convertase are expressed in SCLCs but not in normal lung tissue, they present an attractive target for chemotherapeutic inhibition. In an earlier report we showed that the proliferation of SCLC lines is differentially inhibited by the Bowman-Birk protease inhibitor (BBI; Clark et al. 1993). In that study the in vitro growth of NCI-H345 was significantly inhibited by BBI, whereas the growth of NCI-N592 was unaffected. Western blot analysis with antibodies to GRP showed that the processing of preproGRP in NCI-H345 cells is inhibited by treatment with BBI. As NCI-H345 expresses PC2 (the processing enzyme for preproGRP), we propose that $\mathrm{BBI}$ is inhibiting PC2 activity, which in turn reduces the expression of GRP and thereby reduces the growth of the cell. As NCI-N592 does not express PC2 (Fig. 3), its growth rate is not dependent upon the processing of growth factors by $\mathrm{PC} 2$ and is therefore unaffected by treatment with BBI.

In summary, these observations, together with earlier findings from our laboratory and others, suggest the expression of $\mathrm{PC} 1$ and $\mathrm{PC} 2$ has an important role in the development and maintenance of the SCLC phenotype: prohormone convertase and autocrine growth factor gene expression are linked at the transcriptional level in SCLCs; novel, neuroendocrine-specific transcription factors are involved in the de novo expression of prohormone convertases and autocrine growth factors in SCLCs; and the inhibition of prohormone convertase activity by specific protease inhibitors may reduce the processing of autocrine growth factors and thereby reduce the rate of SCLC proliferation. Subjects for further study include identifying the neuroendocrine-specific transcription factors responsible for the transcriptional activation of prohormone convertase and autocrine growth factor genes in SCLCs. These studies will enable us to define better the genetic and biochemical events that lead to the development of SCLC, and may reveal novel targets and strategies for the treatment of these tumors.

\section{ACKNOWLEDGEMENTS}

This research was funded by a contract from the Arizona Disease Control Research Commission, Phoenix, AZ, USA.

\section{REFERENCES}

Barr PJ 1991 Mammalian subtilisins: the long-sought dibasic processing endoproteases. Cell 66 1-3.

Bean AJ, Dagerlind A, Hökfelt T \& Dobner PR 1992 Cloning of human neurotensin/neuromedin $\mathrm{N}$ genomic sequences and expression in the ventral mesencephalon of schizophrenics and age/sex matched controls. Neuroscience 50 259-268.

Braks JAM \& Martens GJM 1995 7B2 is a neuroendocrine chaperone that transiently interacts with prohormone convertase PC2 in the secretory pathway. Cell 78 263-273.

Carney DN, Gazdar AF, Bepler G, Guccion JG, Marangos PJ, Moody TW, Zweig H \& Minna JD 1985 Establishment and identification of small cell lung cancer cell lines having classic and variant features. Cancer Research 45 2913-2923.

Clark DA, Day R, Seidah N, Moody TW, Cuttitta F \& Davis TP 1993 Protease inhibitors suppress in vitro growth of human small cell lung cancer. Peptides 14 1021-1028.

Cuttitta F, Carney DN, Mulshine J, Moody TW, Fedorko J, Fischler A \& Minna JD 1985 Bombesin-like peptides can function as autocrine growth factors in human small-cell lung cancer. Nature 316 823-826.

Davis TP, Burgess HS, Crowell S, Moody TW, CullingBerglund A \& Liu RH 1989 ß-Endorphin and neurotensin stimulate in vitro clonal growth of SCLC cells. European Fournal of Pharmacology 161 283-285.

Davis TP, Crowell S, McInturff B, Louis R \& Gillespie T 1991 Neurotensin may function as a regulatory peptide in small cell lung cancer. Peptides 12 17-23.

Day R, Schafer MK-H, Watson SJ, Chrétien M \& Seidah NG 1992 Distribution and regulation of the prohormone convertase PC1 and PC2 in the rat pituitary. Molecular Endocrinology 6 485-497.

Evers BM, Wang X, Shou Z, Townsend CM Jr, McNeil GP \& Dobner PR 1995 Characterization of promoter elements required for cell-specific expression of the neurotensin/ neuromedin $\mathrm{N}$ gene in a human endocrine cell line. Molecular and Cellular Biology 15 3870-3881.

Jansen E, Ayoubi TAY, Meulemans SMP \& Van de Ven WJM 1995 Neuroendocrine-specific expression of the human prohormone convertase 1 gene: hormonal regulation of transcription through distinct cAMP response elements. Fournal Biological Chemistry 270 15391-15397.

Jansen E, Ayoubi TAY, Meulemans SMP \& Van de Ven WJM 1997 Cell type-specific protein-DNA interactions at the cAMP response elements of the prohormone convertase 1 promoter: evidence for additional transactivators distinct from CREB/ATF family members. Fournal of Biological Chemistry 272 2500-2508.

Mania-Farnell BL, Botros I, Day R \& Davis TP 1996 Differential modulation of prohormone convertase mRNA by second messenger activators in two cholecystokininproducing cell lines. Peptides 17 47-54.

Mbikay M, Sirois F, Yao J, Seidah JG \& Chrétien M 1997 Comparative analysis of expression of the proprotein convertases furin, PACE4, PC1 and PC2 in human lung tumours. British Fournal of Cancer 75 1509-1514.

Moody TW, Pert CB, Gazdar AF, Carney DN \& Minna JD 1981 High levels of intracellular bombesin characterized human small-cell lung carcinoma. Science 214 1246-1248. 
Moody TW, Lee M, Kris RM, Bellot F, Bepler G, Oie H \& Gazdar AF 1990 Lung carcinoid cell lines have bombesinlike peptides and EGF receptors. Fournal of Cellular Biochemistry 43 139-147.

Nagalla SR \& Spindel ER 1994 Functional analysis of the $5^{\prime}$-flanking region of the human gastrin-releasing peptide gene in small cell lung carcinoma cell lines. Cancer Research 54 4461-4467.

Nakanishi Y, Mulshine JL, Kasprzyk P, Natale RB, Maneckjee R, Avie I, Treston AM, Gazdar AF, Minna JD \& Cuttitta F 1988 Insulin-like growth factor-1 can mediate autocrine proliferation of human small cell lung cancer cell lines in vitro. Fournal of Clinical Investigation 82 354-359.

Ohagi S, LaMendola J, LeBeau MM, Espinosa R III, Takeda J, Smeekens SP, Chan SJ \& Steiner DF 1992 Identification and analysis of the gene encoding human PC2, a prohormone convertase expressed in neuroendocrine tissues. PNAS $\mathbf{8 9}$ 4977-4981.

Rovère C, Barbero P \& Kitabgi P 1996 Evidence that PC2 is the endogenous pro-neurotensin convertase in rMTC 6-23 cells and that PC1 - and PC2-transfected PC12 cells differentially process pro-neurotensin. Fournal of Biological Chemistry 271 11368-11375.

Saldise L, Martínez A, Montuenga LM, Treston A, Springall DR, Polak JM \& Vasquez JJ 1996 Distribution of peptidylglycine alpha-amidating monooxygenase (PAM) enzymes in normal lung and in lung epithelial tumors. Fournal of Histochemistry and Cytochemistry 44 3-12.
Seidah NG, Marcinkiewicz M, Benjannet S, Gaspar L, Beaubien G, Matei MG, Lazure C, Mbikay M \& Chrétien M 1993 Cloning and primary sequence of a mouse candidate prohormone convertase $\mathrm{PC} 1$ homologous to $\mathrm{PC} 2$, furin, and kex2: distinct chromosomal localization and messenger RNA distribution in brain and pituitary compared with PC2. Molecular Endocrinology 5 111-122.

Smeekens SP, Avruch AS, LaMendola J, Chan SJ \& Steiner DF 1991 Identification of a cDNA encoding a second putative prohormone convertase related to PC2 in At'T20 cells and islets of Langerhans. Proceedings of the National Academy of Sciences of the USA 88 340-344.

Steiner DF, Smeekens SP, Ohagi S \& Chan SJ 1992 The new enzymology of precursor processing endoproteases. Fournal of Biological Chemistry 267 23435-23438.

Waters SM, Rounseville MP \& Davis TP 1997 Effect of dopaminergic drugs on processing and degradative neuropeptidase mRNA in rat frontal cortex and caudateputamen. Brain Research 754 28-34.

Zhu X \& Lindberg I 1995 7B2 facilitates the maturation of proPC2 in neuroendocrine cells and is required for the expression of enzymatic activity. Fournal of Cellular Biology 129 1641-1650.

REVISED MANUSCRIPT RECEIVED 14 October 1999 